\title{
Phylogenetic Relationships of Pseudomonas syringae pv. syringae Isolates Associated with Bacterial Inflorescence Rot in Grapevine
}

Stewart J. Hall, National Wine and Grape Industry Centre, Charles Sturt University, New South Wales Department of Primary Industries, Wagga Wagga, NSW, Australia 2650; Ian B. Dry, CSIRO Agriculture, Hartley Grove, Urrbrae, SA, Australia 5064; Christopher L. Blanchard, ARC Industrial Transformation Training Centre for Functional Grains, Charles Sturt University; and Melanie A. WhitelawWeckert, National Wine and Grape Industry Centre, Charles Sturt University, New South Wales Department of Primary Industries

\begin{abstract}
Hall, S. J., Dry, I. B., Blanchard, C. L., and Whitelaw-Weckert, M. A. 2016. Phylogenetic relationships of Pseudomonas syringae pv. syringae isolates associated with bacterial inflorescence rot in grapevine. Plant Dis. 100:607-616.

Pseudomonas syringae pv. syringae causes extensive yield losses in wine-grape production in some Australian cool-climate vineyards. Putative $P$. syringae pv. syringae isolates from infected grapevines within a range of vineyards were genotyped using RNA polymerase $\beta$-subunit $($ rpoB) and multilocus sequence typing (MLST) using primers for glyceraldehyde-3-phosphate dehydrogenase ( gapA), citrate synthase $($ gltA $)$, DNA gyrase B $(g y r B)$, and $\sigma$ factor $70(r p o D)$. The isolates were also evaluated for pathogenicity by inoculation of detached grapevine leaves. The isolates were grouped by MLST data into two wellsupported clades, each containing a mixture of pathogenic and

nonpathogenic grapevine isolates, indicating that $P$. syringae pv. syringae in Australian vineyards is genetically diverse. Each clade also contained $P$. syringae pv. syringae from nongrape hosts pathogenic to grapevine, demonstrating a lack of host specificity and possible potential for cross-infection of grape and other horticultural crops. Furthermore, the isolation of pathogenic $P$. syringae pv. syringae isolates from grapevine sucker shoots suggests that sucker shoots may allow overwintering of the pathogen. The vineyard quarantine status of $P$. syringae pv. syringae may need to be reconsidered, due to its easy dispersal through pruning equipment.
\end{abstract}

In the past decade, wine grape (Vitis vinifera) crops grown in the Tumbarumba viticultural region of southeastern New South Wales have been affected by a new bacterial disease. Grapevine symptoms included leaf spots, necrotic lesions on leaf blades and shoots, and loss of inflorescences early in the season. The disease, "bacterial inflorescence rot" (BIR), is caused by bacterium Pseudomonas syringae pv. syringae (Whitelaw-Weckert et al. 2011). The Tumbarumba region has a cool to moderate climate and is prone to spring frosts (Bureau of Meteorology 2012), so that overhead water sprinkler systems are commonly used to prevent frost damage. It has been proposed that the promotion of humid foliar microclimates by the overhead sprinkler systems may be responsible for some of the grapevine symptoms (Whitelaw-Weckert et al. 2011).

The first report of $P$. syringae foliar symptoms on grapevine was from Argentina, which showed necrotic lesions on petioles, shoots, leaf blades, rachii, and tendrils (Klingner et al. 1976). Several similar reports on grapevine have followed, with reports of bark necrosis (Cugusi et al. 1986), bacteriosis (Samedov et al. 1988), and angular leaf lesions (Hall et al. 2002) caused by $P$. syringae. In these cases, no loss of inflorescences and fruit yield were detailed, and $P$. syringae was considered to be a weak pathogen with little economic impact.

Corresponding author: S. Hall; E-mail: stehall@csu.edu.au

Accession numbers: KJ170133, KJ170135 to KJ170141. KJ170143, KJ170145 to KJ170149, KJ590780 to KJ590798, KJ741398 to KJ741401, KJ939262, KP127628 to KP127634, KP127636 to KP127666, KP136825, KP136833 to KP136834, KP136836 to KP136839, KP136841 to KP136871, KP192332 to KP192338, KP192340 to KP192370, KP229301 to KP229307, and KP229309 to KP229339.

*The $\boldsymbol{e}$-Xtra logo stands for "electronic extra" and indicates that one supple-
mentary table is published online.

Accepted for publication 4 September 2015.

http://dx.doi.org/10.1094/PDIS-07-15-0806-RE

(C) 2016 The American Phytopathological Society
The first observation of bacterial leaf spot (BLS) on wine-grape cultivars in Australian vineyards was reported after heavy rains in the northern Adelaide Hills in October 2000 (Hall et al. 2002). Bacterial "ooze" was observed on necrotic tissue of 'Verdelho' grape and $P$. syringae (pv. unspecified) isolates were collected and deposited in the Australian Collection of Plant Pathogenic Bacteria/New South Wales (NSW) Industry and Investment Culture Collection as DAR73915 and DAR75241. In the following season, further infections were confirmed, with increased severity, spreading to three other nearby South Australian cool wine-growing regions and affecting 'Cabernet Sauvignon', 'Viognier', 'Merlot', 'Sauvignon Blanc', and 'Chardonnay'. Although P. syringae was recovered from lesions on these vines, there was no reported effect on inflorescences or loss of crop (Hall et al. 2002).

The first account of the detrimental effects of $P$. syringae on winegrape yield was not recorded until 2006 (Whitelaw-Weckert et al. 2011). Foliar symptoms similar to those of the Adelaide Hills region were described but with the added loss of inflorescences (BIR) and, thus, yield loss in vineyards across the Tumbarumba region. $P$. syringae pv. syringae was identified from necrotic inflorescences, bacterial ooze, and necrotic spots and lesions on leaves and shoots (Whitelaw-Weckert et al. 2011). Recently, BIR was also reported on V. vinifera in the Sistan region of Iran (Abkhoo 2015).

P. syringae pv. syringae also causes significant economic damage to nonviticultural crops in Australia. It causes bacterial necrosis of mango (Golzar and Cother 2008), leading to necrosis of the panicle and reduced fruit set (Young 2008). It also causes bacterial blight in $40 \%$ of Australian field pea crops, with up to $75 \%$ yield loss in susceptible cultivars (Richardson and Hollaway 2011). Considerable variation in host range may occur between and within the $P$. syringae pathovars (Sawada et al. 1999). For example, $P$. syringae pv. tomato causes a hypersensitivity response (HR) in Arabidopsis and tomato but not bean, whereas $P$. syringae pv. phaseolicola can cause HR in bean and Arabidopsis but not tomato (Feil et al. 2005).

Phylogenetic analysis using polymerase chain reaction (PCR) fingerprinting methods has played an important role in demonstrating hierarchical clustering of bacterial pathogens, including $P$. syringae (Gardan et al. 1999; Hwang et al. 2005; Sarkar et al. 2006; Sawada et al. 1999; Whitelaw-Weckert et al. 2011; Yamamoto et al. 2000). 
Recently, phylogenetic analysis using multilocus sequence typing (MLST) has become an integral tool in bacterial evolution analysis studies. MLST involves the concatenation of a number of core genome sequences that are ubiquitous among all strains of a bacterial species, and which are essential for the survival of the organism (Hwang et al. 2005). These housekeeping genes are chosen on the basis of being less prone to horizontal gene transfer and providing insight into the evolutionary history of bacteria (Hacker and Carniel 2001). This has been demonstrated by Sarkar and Guttman (2004), who determined the evolutionary history of $60 \mathrm{P}$. syringae isolates using seven housekeeping genes such as aconitate hydratase B, phosphofructokinase, phosphoglucoisomerase, and others. Hwang et al. (2005) later refined the number of housekeeping genes to four (citrate synthase, glyceraldehydes-3-phosphate dehydrogenase, DNA gyrase $\mathrm{B}$, and $\sigma$ factor 70 ) in an effort to obtain similar results at a lower cost. The sampling of diverse genomes within a phylogenetic framework can reveal general evolutionary trends indicative of changes in lifestyle. This also allows for the identification of genetic changes that allow differentiation between populations that have recently undergone host range shifts (Sarkar et al. 2006).

MLST has been utilized in an attempt to solve the complex relationships between $P$. syringae pathovars and host range. Several studies have used MLST to detail and clarify whether host range and pathovar can be expressed phylogenetically (Clarke et al. 2010; Hwang et al. 2005; Martín-Sanz et al. 2013; Sarkar and Guttman 2004; Sarkar et al. 2006). Although the selection pressures determining host range may be similar across $P$. syringae pathovars, the sequencing of $P$. syringae pv. syringae genomes across host species has not been sufficiently deep to uncover trends indicating evolutionary differentiation among groups (Lindeberg et al. 2009). The fact that numerous plant species play host to $P$. syringae pv. syringae provides an extra challenge for determining evolutionary differentiation, especially in hosts such as grapevine.

The objectives of this project were to (i) use phylogenetic and molecular techniques to identify $P$. syringae pv. syringae isolates collected from diseased grapevines with symptoms of BIR and BLS, (ii) use MLST to compare pathogenic and nonpathogenic $P$. syringae pv. syringae isolates from the same regions and from other hosts, and (iii) investigate the relationships between the genetic patterns and the virulence of the isolates from grape and other host species.

\section{Materials and Methods}

Four vineyards affected by BIR, three in the Riverina region (Tumbarumba, NSW) and one in the Southern Tablelands (Murrumbateman, NSW), were sampled between September and October 2006, 2011, and 2013. In addition, grapevine samples were obtained from BIR-affected vineyards in the Coonawarra, South Australia (SA) and Piper's River, Tasmania (TAS). Samples were also collected from a vineyard with BLS but no BIR in the Macedon Ranges region (Hanging Rock, Victoria [VIC]), and from apparently healthy grapevines in Victorian vineyards: Glenlofty in the Pyrenees and Hallston in Gippsland. Leaves, shoots, and rachii were collected with ethanol-sterilized equipment, placed into Zip-Lock polyethylene bags, and kept at $4^{\circ} \mathrm{C}$ until bacterial isolation.

Bacterial isolates from culture collections. $P$. syringae pv. morsprunorum (DAR33419) and P. syringae pv. syringae (DAR72042 and DAR73915) were obtained from the NSW Industry and Investment Culture Collection (Orange, Australia). P. syringae isolates BRIP34823, BRIP38670, BRIP34831, BRIP34899, BRIP38817, BRIP34832, BRIP34805, BRIP38811, and BRIP34803 were obtained from the Department of Agriculture, Fisheries and Forestry, Queensland. P. syringae isolates DAR82449, DAR82450, DAR82451, DAR82432, and DAR8453 were obtained from Dr. Thomas Hill, Colorado State University.

Isolation of $\boldsymbol{P}$. syringae. $P$. syringae was isolated from leaves, shoots, and inflorescences of grapevines with apparent BIR symptoms. Plant tissues were rinsed with tap water, surface sterilized with sodium hypochlorite solution ( $1 \%$ available chloride) for $3 \mathrm{~min}$, and then rinsed in three washes of sterile deionized water (SDW). The sterilized tissue was then aseptically cut into approximately 5-by-5-mm pieces, placed on Pseudomonas selective CCF (PS) agar (Oxoid) and incubated in darkness at $25^{\circ} \mathrm{C}$ for up to 3 days. Pseudomonas colonies were then subcultured onto nutrient agar and PS agar to isolate pure colonies. Pure colonies were tested for gram stain, fluorescence under UV light $(254 \mathrm{~nm}$ ), and oxidase production (Lelliott and Stead 1987).

Identification of $\boldsymbol{P}$. syringae. Motile gram-negative, fluorescent, oxidase-negative rod-shaped bacteria were selected and maintained on King's B (KB) agar containing peptone at $20 \mathrm{~g} / \mathrm{liter}, \mathrm{MgSO}_{4}$. $7 \mathrm{H}_{2} \mathrm{O}$ at $1.5 \mathrm{~g} /$ liter, $\mathrm{K}_{2} \mathrm{HPO}_{4}$ at $1.5 \mathrm{~g} /$ liter, $10 \mathrm{ml}$ of glycerol, and agar bacteriological No. 1 (Oxoid) at $15 \mathrm{~g} /$ liter at $25^{\circ} \mathrm{C}$ in darkness. Isolates were tested under the levan and oxidase reaction, potato soft rot, arginine dihydrolyase activity, and tobacco leaf HR (LOPAT) testing scheme (Lelliott and Stead 1987). Pure P. syringae cultures were stored at $-80^{\circ} \mathrm{C}$ in nutrient broth containing $30 \%$ (vol/vol) glycerol. Tests involving 2-keto gluconate production, nitrate reduction, and production of acid from sucrose were also conducted, as previously described by Lelliott and Stead (1987). Pathovars $P$. syringae pv. syringae (from grapevine, cowpea, and stonefruit), $P$. syringae pv. maculicola, $P$. syringae pv. striafaciens, $P$. syringae pv. phaseolicola, $P$. syringae pv. morsprunorum, $P$. syringae pv. mori, and $P$. syringae pv. tabaci were also used to confirm LOPAT identification of $P$. syringae among pathovars.

Koch's postulates. A representative strain of $P$. syringae pv. syringae (DAR82161) from Tumbarumba was tested for its ability to cause disease (spreading necrotic leaf lesions) on leaves on four live potted grapevines (Chardonnay and 'Shiraz'). Prior to inoculation, two leaves per plant were removed and checked for the absence of $P$. syringae pv. syringae infection in asymptomatic or healthylooking plants by surface disinfecting with sodium hypochlorite ( $1 \%$ available chloride) for $1 \mathrm{~min}$, macerating in a mortar and pestle with 5 to $10 \mathrm{ml}$ of sterile phosphate-buffered saline ( $\mathrm{pH} 7)$, serially diluting, spreading $(100 \mu \mathrm{l})$ over PS agar, and incubating at $25^{\circ} \mathrm{C}$ in darkness. After demonstrating the absence of endogenous $P$. syringae pv. syringae in the potted $V$. vinifera Chardonnay and Shiraz plants, the leaves were spray inoculated with a fine mist suspension $\left(1 \times 10^{8} \mathrm{CFU} / \mathrm{ml}\right)$ of $P$. syringae pv. syringae isolate DAR82161 (obtained originally from a necrotic grapevine rachis, Tumbarumba) in SDW until visible run-off. The plants were then enclosed in clear plastic bags to maintain humidity at $>99 \%$, and arranged in randomized complete blocks in a glasshouse maintained at 25 and $15^{\circ} \mathrm{C}$ during day and night, respectively. Potted vines were watered to field capacity twice weekly. Disease development was monitored over 21 days and leaf samples collected at the end of the experiment, at which time leaves were surface sterilized, plated onto PS agar, and incubated under the same conditions as described above.

Grapevine pathogenicity leaf test assay. The grapevine pathogenicity leaf test assay (GPLTA) was carried out as described by Cohen et al. (1999), with minor changes. Briefly, healthy leaves were detached from $V$. vinifera Chardonnay plants (grown under greenhouse conditions) and were surface sterilized in $1 \%$ available chloride solution containing TWEEN 80 detergent (Sigma) at $100 \mu 1 /$ liter for $3 \mathrm{~min}$, followed by four washes in sterile distilled water. Leaf discs (12 $\mathrm{mm}$ in diameter) were aseptically cut with a number 8 cork borer (12 $\mathrm{mm}$ in diameter) and placed abaxial side up on $1 \%$ agar. For inoculations, $50-\mu 1$ drops of test bacteria were spot inoculated onto leaf discs at concentrations of approximately $1 \times 10^{8} \mathrm{CFU} / \mathrm{ml}$ and incubated at $25^{\circ} \mathrm{C}$ for up to 7 days in a moist sealed bag at relative humidity of $>99 \%$ in an Intellus Control System Incubator (Percival). Isolates were considered pathogenic to grapevine if typical necrotic symptoms (i.e., appearance of brown lesions at the point of inoculation) appeared within 2 days and were observed over 7 days.

RNA polymerase $\boldsymbol{\beta}$-subunit gene analysis. Cultures grown on $\mathrm{KB}$ agar for $48 \mathrm{~h}$ in darkness were used for DNA extraction, using a DNeasy Blood and Tissue Kit (Qiagen) following the manufacturer's instructions. The RNA polymerase $\beta$-subunit gene (rpoB) was used for pathovar identification by PCR. The primers used for $r p o B$ (Table 1) have been previously shown to amplify a 1,247-bp fragment from Pseudomonas spp. (Ait-tayeb et al. 2005). PCR reactions $(25 \mu \mathrm{l})$ were carried out using a BioRad C1000 Thermal Cycler 
with GoTaq Green polymerase (Promega) according to the manufacturer's instructions, with a final primer concentration of $0.3 \mu \mathrm{M}$ and approximately $100 \mathrm{ng}$ of template DNA. Cycle conditions were $94^{\circ} \mathrm{C}$ for $3 \mathrm{~min}$; then, 40 cycles of $94^{\circ} \mathrm{C}$ for $45 \mathrm{~s} 55^{\circ} \mathrm{C}$ for $1 \mathrm{~min}$, and $72^{\circ} \mathrm{C}$ for $90 \mathrm{~s}$; with a final extension step of $72^{\circ} \mathrm{C}$ for $10 \mathrm{~min}$.

MLST. The four housekeeping genes used for MLST were gapA, encoding glyceraldehyde-3-phosphate dehydrogenase; glt $A$, encoding citrate synthase (also known as $c t s$ ); gyrB, encoding DNA gyrase $\mathrm{B}$; and $r p o D$, encoding $\sigma$ factor 70 . The MLST protocol was carried out essentially as described by Hwang et al. (2005). PCR was carried out as described above, with the following cycle conditions: $94^{\circ} \mathrm{C}$ for $2 \mathrm{~min}, 60^{\circ} \mathrm{C}$ for $1 \mathrm{~min}$, and $72^{\circ} \mathrm{C}$ for $1 \mathrm{~min}$ for 36 cycles, using primers outlined in Table 1.

PCR products were purified using a PCR Purification Kit (Qiagen) following the manufacturer's instructions and quantified on a $1 \%$ agarose gel stained with ethidium bromide. The purified products were sequenced by the Australian Genome Research Facility. Sequence data were analyzed using MEGA5 software and aligned using CLUSTAL W. A BLAST search was conducted on trimmed rрoB sequences to confirm identity and to determine the pathovar. P. syringae pv. morsprunorum (DAR33419) and P. syringae pv. syringae (DAR72042) were also used in this study as negative and positive controls, respectively, and P. fragi ST128 (isolated from a grapevine, Hanging Rock, VIC) was used as the outgroup. Separate phylogenetic trees were generated using neighbor-joining (NJ; rpoB and MLST data) and unweighted pair-group method with arithmetic mean (UPGMA; rpoB data) with Jukes-Cantor corrected distances (Jukes and Cantor 1969; Kumar et al. 2004) and statistical confidence for sequence groups determined using a bootstrap test with 1,000 pseudoreplicates (Felsenstein 1985).

Accession numbers. Sequence data obtained in this study were deposited into GenBank (Supplementary Table S1).

\section{Results}

In order to investigate the genetic diversity of $P$. syringae pv. syringae isolates present in Australian vineyards affected by BIR, isolates were collected from symptomatic diseased grapevines (Fig. 1). Symptoms of grapevine BIR or BLS included leaf spots with yellow chlorotic haloes (Fig. 1A), necrotic lesions on shoots (Fig. 1B), bacterial ooze and abscised flowers in inflorescences (Fig. 1C), and death of inflorescences (Fig. 1D). Abscission of the necrotic inflorescences occurred in most cases, resulting in full loss of grape bunches. Once established in a vineyard, the severity of these symptoms generally progressed over the following seasons.

$P$. syringae was isolated from all surface-sterilized diseased grapevine tissues with BIR and BLS symptoms. Bacterial ooze emerging from the diseased plant tissue and from surfaced-sterilized plant tissue on PS agar consisted of pure cultures of motile oxidase-negative, fluorescent gram-negative bacilli, 0.5 to $1.0 \mu \mathrm{m}$ wide and 2.0 to $3.0 \mu \mathrm{m}$ long. Colonies produced yellow pigment on PS and KB agar that fluoresced blue under UV light ( $254 \mathrm{~nm}$; data not shown). These features are consistent with those of $P$. syringae.

The $P$. syringae isolates were then further characterized using the LOPAT testing regime, which enables the separation of plant saprophytic pseudomonads from pathogenic pseudomonads (Lelliott and Stead 1987). All the $P$. syringae isolates were positive for levan-type colonies on sucrose agar but were negative for oxidase reaction, potato soft rot, and arginine dihydrolyase activity (Lelliott and Stead 1987; Lelliott et al. 1966). Nonpathogenic grapevine P. syringae pv. syringae isolates (DAR82449, DAR82450, DAR82451, and DAR82452) were unable to cause tobacco leaf HR (Table 2).

Further characterization involved tests for 2-keto gluconate production, nitrate reduction, and acid production from sucrose. The results indicate that most isolates of $P$. syringae were unable to produce 2-keto gluconate from gluconate or to reduce nitrate but were positive for acid production from sucrose. In contrast, one isolate (BRIP34823, P. syringae pv. syringae from cowpea) was able to produce 2-keto gluconate from gluconate and to reduce nitrate. These results further verified the identification of most of the isolates as LOPAT group 1a $P$. syringae from grapevine (Lelliott and Stead 1987). Interestingly, DAR82445, DAR82447, DAR82443, and DAR82162, isolated from grapevine sucker shoots (latent buds that
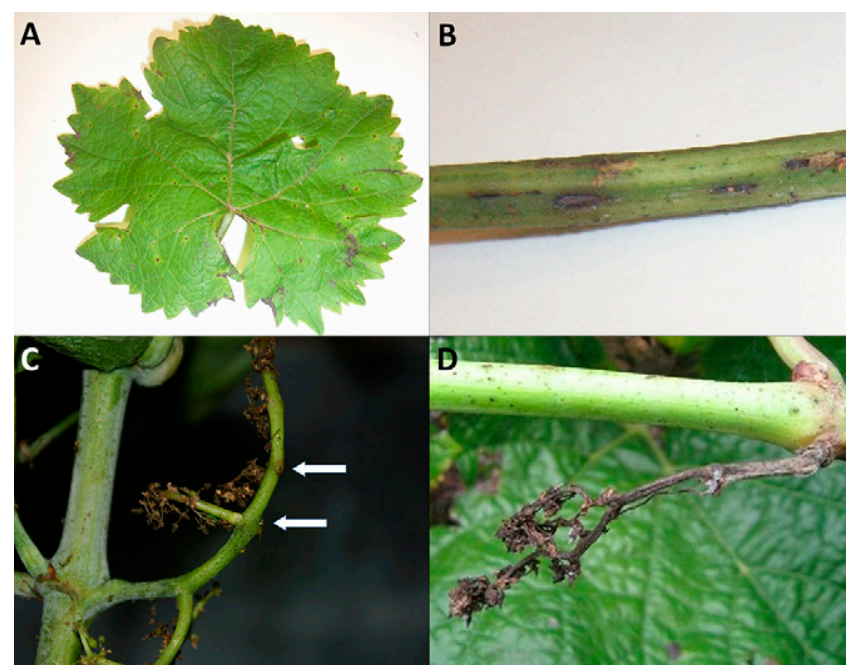

Fig. 1. A, Riesling with symptoms of dark leaf spots with yellow chlorotic haloes, Tumbarumba, NSW. B, Riesling petiole with longitudinal necrotic lesions (Tumbarumba, NSW). C, Riesling inflorescence affected by bacterial inflorescence rot; bacterial ooze (arrows) and abscised flowers (Tumbarumba, NSW). D, Necrotic rachis on Cabernet Sauvignon (from field grapevine, Coonawarra, SA). Images supplied by L. Quirk (C), DPI NSW, and N. Scarlett (deceased), Rathbone Wine Group, Melbourne, VIC. (D).

Table 1. Primers used for $r p o B$ and multilocus sequence typing (MLST)

\begin{tabular}{llll}
\hline Primer $^{\mathbf{a}}$ & \multicolumn{1}{c}{ Sequence } & \multicolumn{1}{c}{ Function } & \multicolumn{1}{c}{ Authors } \\
\hline LAPSps & TGGCCGAGAACCAGTTCCGCG & Pathovar identification & Ait-tayeb et al. 2005 \\
LAPS27ps & CGGCTTCGTCCAGCTTGTTCA & Pathovar identification & Ait-tayeb et al. 2005 \\
gapA+264p & CCGGCSGARCTGCCSTGG & MLST & Sarkar and Guttman 2004; Hwang et al. 2005 \\
gapA+312s & CGARTGCACSGGBCTSTTCACC & MLST & Sarkar and Guttman 2004; Hwang et al. 2005 \\
gapA-874ps & GTGTGRTTGGCRTCGAARATCGA & MLST & Sarkar and Guttman 2004; Hwang et al. 2005 \\
gltA+174p & CCTCBTGCGAGTCGAAGATCACC & MLST & Sarkar and Guttman 2004; Hwang et al. 2005 \\
gltA+513s & CTGRTCGCCAAGATGCCGAC & MLST & Sarkar and Guttman 2004; Hwang et al. 2005 \\
gltA-1130s & CGAAGATCACGGTGAACATGCTGG & MLST & Sarkar and Guttman 2004; Hwang et al. 2005 \\
gltA-1192p & CTTGTAVGGRCYGGAGAGCATTTC & MLST & Sarkar and Guttman 2004; Hwang et al. 2005 \\
gyrB+271ps & CBGCRGCVGARGTSATCATGAC & MLST & Sarkar and Guttman 2004; Hwang et al. 2005 \\
gyrB-1022ps & TTGTCYTTGGTCTGSGAGCTGAA & MLST & Sarkar and Guttman 2004; Hwang et al. 2005 \\
rpoD+174p & AGGTGGAAGACATCATCCGCATG & MLST & Sarkar and Guttman 2004; Hwang et al. 2005 \\
rpoD+364s & YGAAGGCGARATYGRAATCG & MLST & Sarkar and Guttman 2004; Hwang et al. 2005 \\
rpoD-1222ps & CCGATGTTGCCTTCCTGGATCAG & MLST & Sarkar and Guttman 2004; Hwang et al. 2005 \\
\hline
\end{tabular}

${ }^{a}$ Forward-strand primer (+), reverse-strand primer (-), PCR primer (p), and sequencing primer (s). 
sprout from the crown, the basal region of the trunk slightly below and above the soil level, of the grapevine trunk) in BIR-affected Tumbarumba vineyards had results for LOPAT, 2-keto gluconate production, nitrate reduction, and acid production from sucrose identical to those of the $P$. syringae pv. syringae pathogens isolated from infected rachi in the same vineyards (Table 2).

To confirm that $P$. syringae pv. syringae was responsible for the disease development on grapevine, Koch's postulates were tested by inoculating leaves of potted $V$. vinifera Chardonnay and Shiraz plants with a representative strain of $P$. syringae pv. syringae (DAR82161) and maintaining the leaves under humid conditions. Leaf lesions developed similarly to those observed in vineyardinfected material, with dark necrotic spots with yellow chlorotic haloes appearing on the leaves within $48 \mathrm{~h}$ postinoculation (Fig. 2A). These lesions progressed along the veins to noninoculated regions (Fig. 2A), until the leaves senesced (Fig. 2B). After 3 weeks postinoculation, tissue samples were collected and $P$. syringae pv. syringae was recovered from the leaves as described above. No P. syringae was isolated from the noninoculated plants, thus confirming Koch's postulates.

The remainder of the $P$. syringae isolates collected were also assessed for their ability to cause necrosis on detached grapevine leaf discs using the GPLTA. All $P$. syringae pv. syringae isolates obtained from grapevines displaying BIR or BLS produced necrosis in the GPLTA whereas grapevine isolates from healthy vineyards (i.e., DAR82449, DAR82450, DAR82451, and DAR82452) did not. Interestingly, some $P$. syringae pv. syringae isolates from nongrape hosts (e.g., DAR72042 from apple leaf spot, Batlow, NSW; BRIP34823 isolated from cowpea showing leaf necrosis; and BRIP38670, BRIP38817, and BRIP34899 from stone fruit trees with canker) gave positive GPLTA results. Of the non-syringae

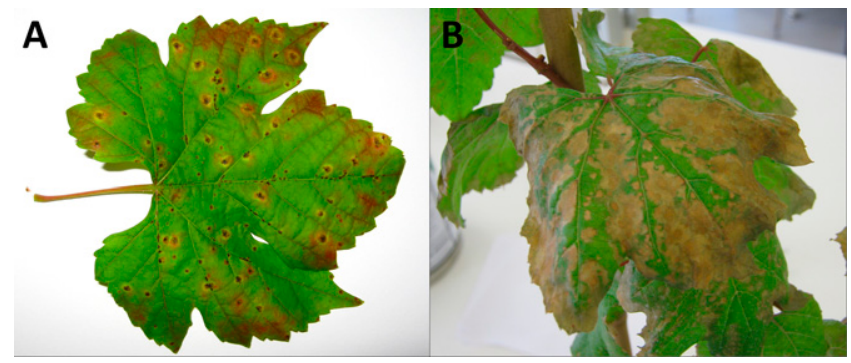

Fig. 2. Symptoms of Pseudomonas syringae pv. syringae infection on leaves from potted grapevines used to test Koch's postulates. A, Potted Shiraz leaf showing dark bacterial leaf spots with yellow chlorotic haloes after $48 \mathrm{~h}$ post spray inoculation. B, Leaf senescence on potted Chardonnay grapevine 4 days post spray inoculation with $P$. syringae pv. syringae.

Table 2. Levan and oxidase reaction, potato soft rot, arginine dihydrolyase activity, and tobacco leaf hypersensitivity response identification of Pseudomonas syringae $^{\mathrm{a}}$

\begin{tabular}{|c|c|c|c|c|c|c|c|c|c|}
\hline Isolate & Lev & $\mathbf{O x}$ & Pot & Arg & Tob & $2 \mathrm{KG}$ & NR & AFS & P. syringae pv. \\
\hline DAR33419 & + & - & - & - & + & - & - & + & morsprunorum \\
\hline DAR72042 & + & - & - & - & + & - & - & + & syringae \\
\hline DAR73915 & + & - & - & - & + & - & - & + & syringae \\
\hline DAR77819 & + & - & - & - & + & - & - & + & syringae \\
\hline DAR77820 & + & - & - & - & + & - & - & + & syringae \\
\hline DAR82159 & + & - & - & - & + & - & - & + & syringae \\
\hline DAR82160 & + & - & - & - & + & - & - & + & syringae \\
\hline DAR82161 & + & - & - & - & + & - & - & + & syringae \\
\hline DAR82162 & + & - & - & - & + & - & - & + & syringae \\
\hline DAR82165 & + & - & - & - & + & - & - & + & syringae \\
\hline DAR82166 & + & - & - & - & + & - & - & + & syringae \\
\hline DAR82169 & + & - & - & - & + & - & - & + & syringae \\
\hline DAR82170 & + & - & - & - & + & - & - & + & syringae \\
\hline DAR82171 & + & - & - & - & + & - & - & + & syringae \\
\hline DAR82440 & + & - & - & - & + & - & - & + & syringae \\
\hline DAR82441 & + & - & - & - & + & - & - & + & syringae \\
\hline DAR82442 & + & - & - & - & + & - & - & + & syringae \\
\hline DAR82443 & + & - & - & - & + & - & - & + & syringae \\
\hline DAR82444 & + & - & - & - & + & - & - & + & syringae \\
\hline DAR82445 & + & - & - & - & + & - & - & + & syringae \\
\hline DAR82446 & + & - & - & - & + & - & - & + & syringae \\
\hline DAR82447 & + & - & - & - & + & - & - & + & syringae \\
\hline DAR82448 & + & - & - & - & + & - & - & + & syringae \\
\hline DAR82449 & + & - & - & - & - & - & - & + & syringae \\
\hline DAR82450 & + & - & - & - & - & - & - & + & syringae \\
\hline DAR82451 & + & - & - & - & - & - & - & + & syringae \\
\hline DAR82452 & + & - & - & - & - & - & - & + & syringae \\
\hline DAR82453 & + & - & - & - & + & - & - & + & syringae \\
\hline BRIP34803 & + & - & - & - & + & - & - & + & tabaci \\
\hline BRIP34805 & + & - & - & - & + & - & - & + & mori \\
\hline BRIP34823 & + & - & - & - & + & + & + & + & syringae \\
\hline BRIP34831 & + & - & - & - & + & - & - & + & syringae \\
\hline BRIP34832 & + & - & - & - & + & - & - & + & striafaciens \\
\hline BRIP34899 & + & - & - & - & + & - & - & + & syringae \\
\hline BRIP38670 & + & - & - & - & + & - & - & + & syringae \\
\hline BRIP38811 & + & - & - & - & + & - & - & + & phaseolicola \\
\hline BRIP38817 & + & - & - & - & + & - & - & + & maculicola \\
\hline ST128 & + & - & - & - & - & - & - & - & fragi \\
\hline
\end{tabular}

${ }^{\mathrm{a}} \mathrm{Lev}=$ levan like colonies, $\mathrm{Ox}=$ oxidase reaction, $\mathrm{Pot}=$ potato rot assay, $\mathrm{Arg}=$ arginine dihydrolase activity, $\mathrm{Tob}=$ tobacco leaf hypersensitivity reaction, $2 \mathrm{KG}=$ 2-keto gluconate production from gluconate, $\mathrm{NR}=$ nitrate reduction, and $\mathrm{AFS}=$ acid from sucrose.

b Pathovar as determined from rpoB sequencing. 
pathovars, $P$. syringae pv. maculicola (BRIP38817 from diseased cabbage), $P$. syringae pv. striafaciens (BRIP34832 isolated from oat with leaf spot), and $P$. syringae pv. tabaci (BRIP34803 from soybean with leaf spot) gave positive GPLTA results, whereas BRIP38811 (pv. phaseolicola isolated from bean with leaf spot), BRIP34805 (pv. mori from white mulberry), and DAR33419 (pv. morsprunorum from a wild cherry leaf) were negative for GPLTA but were positive for the tobacco leaf HR (Table 3).

$r p o B$ gene sequencing was used as the final step in $P$. syringae pathovar identification. When purified $r p o B$ PCR products from all isolates were sequenced and BLAST searches conducted, grapevine $P$. syringae isolates were identified as $P$. syringae pv. syringae, with $100 \%$ similarity to $P$. syringae pv. syringae B728a (accession number CP000075) (Table 3). The rpoB sequence of the representative grapevine $P$. syringae pv. syringae BIR isolate, DAR82448 from Tumbarumba, was identical to the sequence for a leaf spot isolate (DAR73915) originally collected from an Adelaide Hills vineyard in 2000. It was also identical with $P$. syringae pv. syringae isolates from three Tumbarumba vineyards associated with loss of crop yield in the field due to inflorescence necrosis: DAR82171 from a diseased cane, DAR82169 from an infected rachis, and DAR8244 and DAR82446 from sucker shoots. In contrast, some known BIR $P$. syringae pv. syringae isolates differed by 3 to 7 nucleotides (nt) (of $426 \mathrm{nt}$ ) from DAR82448, showing that this group of pathogens include some genetically relatively dissimilar $P$. syringae pv. syringae isolates.

The $r p o B$ sequences were used to produce a phylogenetic tree inferred using the NJ method, which showed $P$. syringae pv. syringae to be separated from the other $P$. syringae pathovars, albeit with low bootstrap support (42\%). The rpoB sequences of seven of the Tumbarumba grapevine isolates clustered with the Adelaide Hills isolate (DAR73915), with $87 \%$ bootstrap support (Fig. 3). The NJ method was found to be superior to UPGMA for generating a useful phylogenetic tree. The evolutionary distances in the UPGMA tree were not well expressed due to high levels of heterogeneity and weak bootstrap support (data not shown).

MLST has been used to produce phylogenetic trees with higher discriminatory power, resulting in clearer assumptions on evolutionary

Table 3. Characteristics of isolates of Pseudomonas syringae pv. syringae from Australian vineyards with symptoms of bacterial inflorescence rot ${ }^{\mathrm{a}}$

\begin{tabular}{|c|c|c|c|c|c|}
\hline Isolate $^{b}$ & Host & Host symptom & Host origin ${ }^{\mathrm{c}}$ & GLPTA $^{d}$ & $\operatorname{rpoB}(\mathrm{nt})^{\mathrm{e}}$ \\
\hline Pss DAR72042 & Malus $\times$ domestica (apple) Royal Gala & Leaf spot & Batlow, BLS, 1997 & + & 4 \\
\hline Pss DAR73915 & Vitis vinifera, unspecified cultivar & Leaf spot & Adelaide Hills, BLS, 2000 & + & 0 \\
\hline Pss DAR77819 & V. vinifera Sauvignon Blanc & Necrotic rachis & Tumbarumba, BIR, 2006 & + & 3 \\
\hline Pss DAR77820 & V. vinifera Sauvignon Blanc & Shriveled berry & Tumbarumba, BIR, 2006 & + & 3 \\
\hline Pss DAR82159 & V. vinifera Pinot Noir & Shriveled berry & Tumbarumba, BIR, 2011 & + & 3 \\
\hline Pss DAR82160 & V. vinifera Pinot Noir & Cane necrotic lesion & Tumbarumba, BIR, 2011 & + & 1 \\
\hline Pss DAR82161 & V. vinifera Pinot Noir & Necrotic rachis & Tumbarumba, BIR, 2011 & + & 1 \\
\hline Pss DAR82162 & V. vinifera Pinot Noir & Sucker shoot necrotic lesion & Tumbarumba, BIR, 2011 & + & 7 \\
\hline Pss DAR82165 & V. vinifera Pinot Noir & Shoot necrotic lesion & Tumbarumba, BIR, 2011 & + & 4 \\
\hline Pss DAR82166 & V. vinifera Pinot Noir & Leaf spot & Tumbarumba, BIR, 2011 & + & 4 \\
\hline Pss DAR82169 & V. vinifera Pinot Noir & Necrotic rachis & Tumbarumba, BIR 2006 & + & 0 \\
\hline Pss DAR82170 & $V$. vinifera Riesling & Shoot necrotic lesion & Tumbarumba, BIR, 2006 & + & 5 \\
\hline Pss DAR82171 & V. vinifera Pinot Noir & Cane necrotic lesion & Tumbarumba, BIR, 2011 & + & 0 \\
\hline Pss DAR82440 & V. vinifera Pinot Noir & Shriveled berry & Murrumbateman, BIR, 2013 & + & 6 \\
\hline Pss DAR82441 & V. vinifera Chardonnay & Leaf spot & Hanging Rock, BLS, 2013 & + & 4 \\
\hline Pss DAR82442 & V. vinifera Pinot Noir & Necrotic rachis & Piper's River, BIR, 2014 & + & 7 \\
\hline Pss DAR82443 & V. vinifera Pinot Noir & Sucker cane necrotic lesion & Tumbarumba, BIR, 2013 & + & 5 \\
\hline Pss DAR82444 & V. vinifera Pinot Noir & Sucker shoot necrotic lesion & Tumbarumba, BIR, 2013 & + & 0 \\
\hline Pss DAR82445 & V. vinifera Pinot Noir & Leaf spot & Tumbarumba, BIR, 2013 & + & 4 \\
\hline Pss DAR82446 & V. vinifera Pinot Noir & Sucker shoot necrotic rachis & Tumbarumba, BIR, 2013 & + & 0 \\
\hline Pss DAR82447 & V. vinifera Pinot Noir & Sucker shoot necrotic rachis & Tumbarumba, BIR, 2013 & + & 4 \\
\hline Pss DAR82448 & V. vinifera Pinot Noir & Necrotic rachis & Tumbarumba, BIR, 2013 & + & \\
\hline Pss DAR82449 & V. vinifera frost affected Chardonnay & Shoot lesion & Glenlofty, ND, 2007 & - & 7 \\
\hline Pss DAR82450 & V. vinifera frost affected Chardonnay & Shoot lesion & Glenlofty, ND, 2007 & - & 7 \\
\hline Pss DAR82451 & V. vinifera Chardonnay & Healthy shoot & Hallston, ND, 2007 & - & 3 \\
\hline Pss DAR82452 & V. vinifera Chardonnay & Healthy shoot & Hallston, ND, 2007 & - & 7 \\
\hline Pss DAR82453 & V. vinifera Cabernet Sauvignon & Necrotic rachis & Coonawarra, BIR, 2010 & + & 9 \\
\hline Pss BRIP34823 & $\begin{array}{l}\text { Vigna unguiculata subsp. unguiculata } \\
\text { (cow pea) }\end{array}$ & Leaf spot & Toowoomba, BLS, 1971 & + & 4 \\
\hline Pss BRIP34831 & Prunus americana (American plum) & Canker & Stanthorpe, C, 1981 & - & 7 \\
\hline Pss BRIP34899 & $P$. persica $($ peach $)$ & Canker & Not specified (VIC), C, 1971 & + & 7 \\
\hline Pss BRIP38670 & P. americana (American plum) & Canker & Mount Tully, C, 1972 & + & 6 \\
\hline Pmo BRIP34805 & Morus alba L. (white mulberry) & Not specified & Stanthorpe, 1980 & - & 22 (Pmo) \\
\hline Psm BRIP38817 & $\begin{array}{l}\text { Brassica oleracea var. capitata (L.) Alef. } \\
\text { (cabbage) }\end{array}$ & Not specified & Marcoola Beach, 1978 & + & 12 (Psm) \\
\hline Psm DAR33419 & P. avium (wild cherry) & Leaf & Armidale, 1975 & - & 23 (Psm) \\
\hline Psp BRIP38811 & Phaseolus vulgaris (common bean) & Bean spot & Benora Point, 1977 & - & 20 (Psp) \\
\hline Pstab BRIP34803 & Glycine $\max$ (L.) Merr. (soybean) & Not specified & Not specified (VIC), 1980 & + & 20 (Ptab) \\
\hline Pstr BRIP34832 & Avena spp. (oat) & Not specified & Wyaga, 1981 & + & 19 (Pstr) \\
\hline P. fragi (ST128) & Vitis vinifera Sauvignon Blanc & Cane bacterial ooze & Hanging Rock, 2013 & - & 37 (P. fragi) \\
\hline
\end{tabular}

a Comparison of $P$. syringae pv. syringae rpoB sequences with that of the known Tumbarumba bacterial inflorescence rot isolate, DAR82448.

b Pss: P. syringae pv. syringae; Pma: P. syringae pv. maculicola; Pstr: P. syringae pv. striafaciens; Psm: P. syringae pv. morsprunorum; Pmo: $P$. syringae pv. mori; Php: P. syringae pv. phaseolicola; and Pstab: P. syringae pv. tabaci.

${ }^{c} \mathrm{BIR}=$ bacterial inflorescence rot affected vineyard, BLS = bacterial leaf spot affected vineyard, ND = vineyard not affected by leaf spot or bacterial inflorescence rot, and $\mathrm{C}=$ canker

${ }^{\mathrm{d}}$ Grapevine pathogenicity leaf test assay: positive (+) or negative (-) for necrosis on leaf disc.

e Number of $r p o B$ nucleotides (nt) different from DAR82448 (out of $426 \mathrm{nt}$ ). 
history. MLST was performed on all isolates in this study to produce a phylogenetic tree from concatenated sequence data. The MLST data were used to produce an NJ phylogenetic tree with higher discrimination and stronger bootstrap support for the separation of $P$. syringae pv. syringae from other pathovars of $P$. syringae. The analysis indicates the existence of three clades with strong bootstrap support. Clade 1 (98\% bootstrap support) contains mainly pathogenic grapevine $P$. syringae pv. syringae isolates from NSW (Tumbarumba and Murrumbateman), South Australia (Adelaide Hills and Coonawarra), Victoria (Macedon Ranges), and Tasmania (Piper's River). It also contains one cow pea isolate from Queensland (Toowoomba) that is pathogenic on grapevine (Table 3) and four nonpathogenic grape isolates from Victoria. Clade 2 (100\% bootstrap support) contains isolates collected from apricot (one pathogenic and one nonpathogenic), peach (pathogenic), and grapevine (one pathogenic and one nonpathogenic). Clade 3 contains other pathovars tested in this study (including pvs. tabai, mori, morsprunorum, maculicola, striafaciens, and phaseolicola; Fig. 4).

\section{Discussion}

Distribution in Australian vineyards. This study has used phylogenetic and molecular techniques to investigate the genetic diversity of $P$. syringae pv. syringae isolates from diseased vines of wine-grape cultivars in Australian vineyards. Included were isolates from grapevines displaying symptoms of BIR or BLS, alone or in combination, within eight vineyards situated in six different viticultural regions across Australia. P. syringae pv. syringae was isolated from diseased grapevines in the following cool-climate vineyards

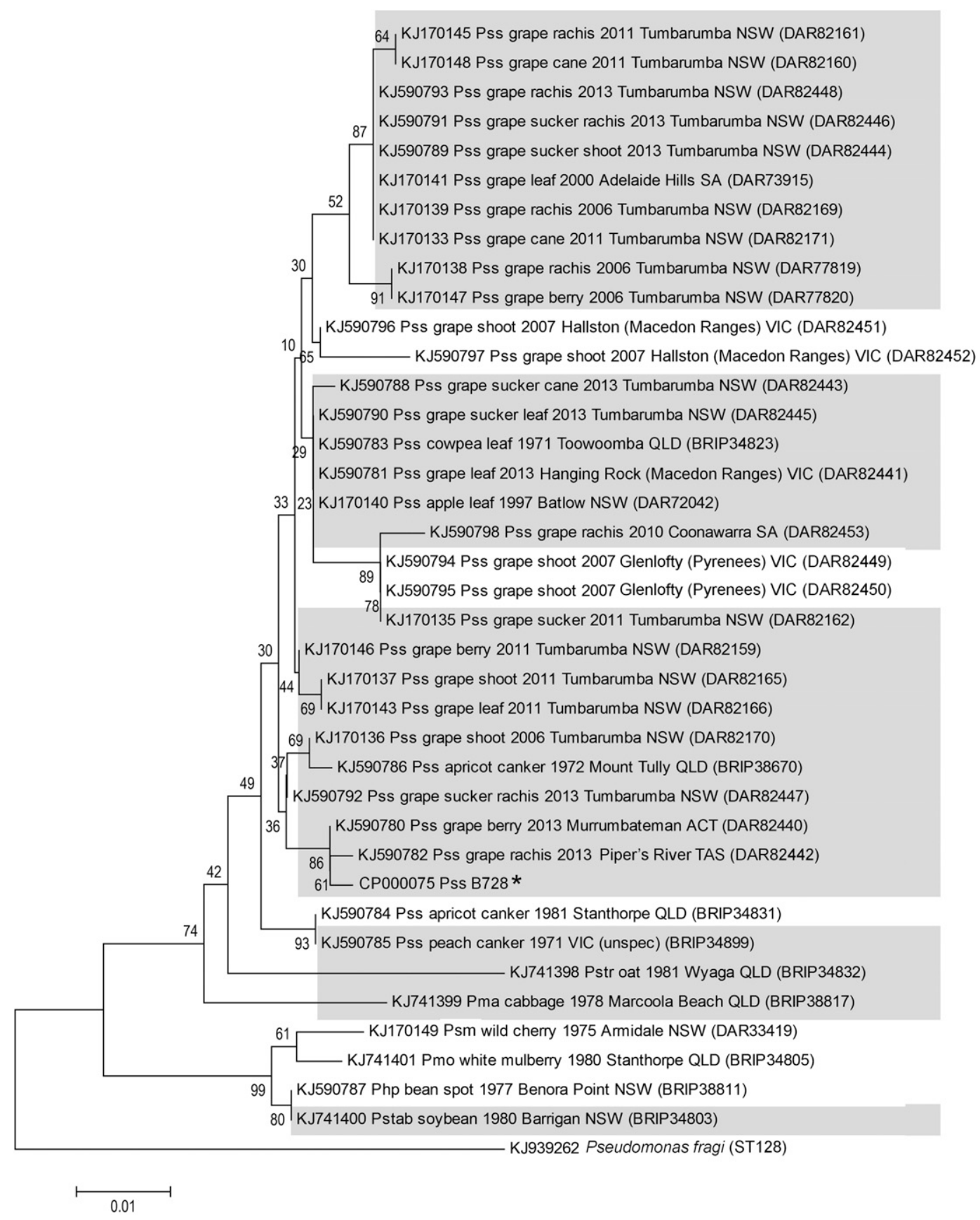

Fig. 3. Phylogenetic relationships between Pseudomonas spp. based on rpoB sequence. The evolutionary relatedness was inferred using the Neighbor-Joining method. (Saitou and Nei 1987). Isolates that are pathogenic on grapevine leaves are shaded. Pss: P. syringae pv. syringae; Pma: P. syringae pv. maculicola; Pstr: P. syringae pv. striafaciens; Psm: $P$. syringae pv. morsprunorum; Pmo: P. syringae pv. mori; Php: P. syringae pv. phaseolicola; and Pstab: $P$. syringae pv. tabaci. Asterisk ( $\left.{ }^{*}\right)$ indicates that these sequence data were downloaded from GenBank and not tested for grapevine pathogenicity. Numbers on nodes are bootstrap values, the frequency (\%) with which a cluster appeared in a bootstrap test of 1,000 runs. 
affected by BIR: three in Tumbarumba, NSW; one in Murrumbateman, Southern Tablelands, NSW; one in Piper's River, TAS; and one in Coonawarra, SA. We also isolated $P$. syringae pv. syringae from diseased grapevines in a cool-climate vineyard with BLS symptoms only (Hanging Rock, Macedon Ranges, VIC) and a culture collection isolate from an Adelaide Hills, SA cool-climate vineyard with BLS (Hall et al. 2002). Finally, we isolated nonpathogenic P. syringae pv. syringae from apparently healthy grapevines in cool-climate Victorian vineyards not affected by BIR at Glenlofty, Pyrenees and at Hallston, Gippsland (Fig. 5).
Hall et al. (2002) originally reported $P$. syringae as a weak pathogen of grapevines in the Adelaide Hills region. In that investigation, $P$. syringae pv. syringae caused no yield loss, although it did cause increasingly severe foliar symptoms in subsequent seasons. A table-grape vineyard in Mildura, VIC, watered with overhead water sprinklers, also recorded symptoms of $P$. syringae BIR in 1998, 2001, 2004, and 2014 on 'Sultana' and 'Red Globe' grape (C. Skyllas, Victorian Department of Environment and Primary Industries, personal communication). Bacterial isolates from the Mildura table-grape vineyard could not be obtained for our study and,

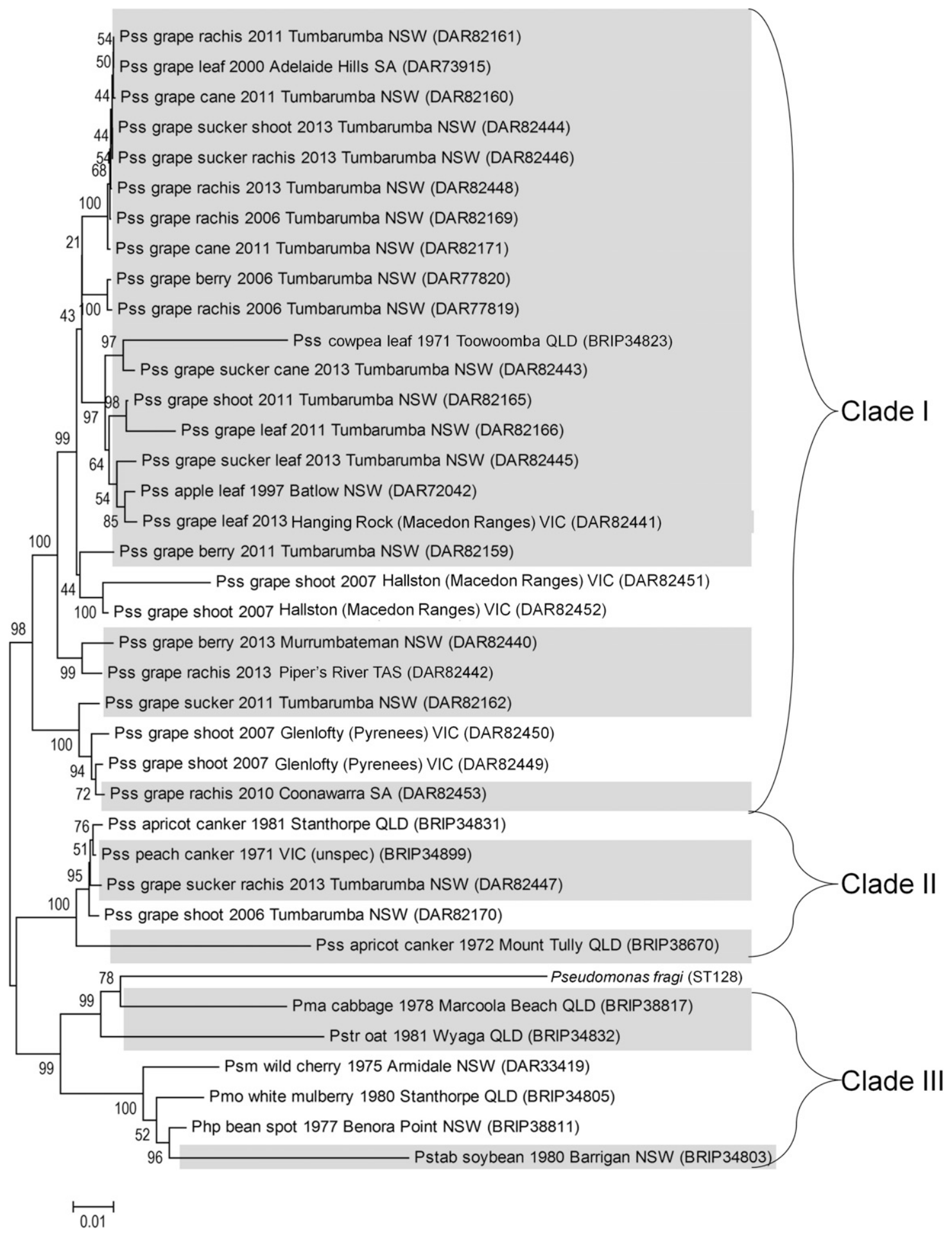

Fig. 4. Phylogenetic relationships between $P$ seudomonas spp. based on gapA, glt $A$, gyrB, and $r p o D$ concatenated multilocus sequence typing data. Evolutionary relatedness was inferred using the neighbor-joining method (Saitou and Nei 1987). Isolates that are pathogenic on grapevine leaves are shaded. Pss: P. syringae pv. syringae; Pma: P. syringae pv. maculicola; Pstr: P. syringae pv. striafaciens; Psm: P. syringae pv. morsprunorum; Pmo: P. syringae pv. mori; Php: P. syringae pv. phaseolicola; and Pstab: P. syringae pv. tabaci. Numbers on nodes are bootstrap values, the frequency (\%) with which a cluster appeared in a bootstrap test of 1,000 runs. 
therefore, could not be compared with the cool-climate wine-grape Australian isolates of $P$. syringae pv. syringae. However, the collection dates indicate that symptoms of BIR caused by $P$. syringae may predate the report of Hall et al. (2002).

Infection of grapevine. The observed symptoms produced by $P$. syringae pv. syringae on grapevine (necrotic lesions on leaf tissue, shoots, and inflorescences) are in agreement with those previously reported for BIR by Whitelaw-Weckert et al. (2011) and Abkhoo (2015). P. syringae pv. syringae, which has an extensive plant host range, can be widely distributed on plant surfaces, water, and soil. Following heavy spring rains, the bacterium spreads across wet plant surfaces on shoots and inflorescences and through the leaf stomata (Melotto et al. 2006). In grapevine, $P$. syringae pv. syringae infection starts in the leaves (BLS), followed by systemic movement of bacteria to the bunch rachis (BIR) (Whitelaw-Weckert et al. 2011). BIR of immature grapevine inflorescences shows similarities to a disease of immature fruit blossoms by $P$. syringae pv. syringae in other woody fruit trees: apple (Mansvelt and Hattingh 1989), lychee (Alfrose et al. 2014), mango (Cazorla et al. 1998; Golzar and Cother 2008; Young 2008); pear (Mansvelt and Hattingh 1987; Moragrega et al. 2003), and stone fruit (Little et al. 1998).

Because $P$. syringae pv. syringae is a relatively new pathogen to the wine industry, symptoms on grapevine may be misidentified as other pathological or physiological conditions. Some symptoms of BIR may have previously been attributed to Botrytis cinerea, which causes gray mold of grape bunches. $B$. cinerea can infect inflorescences early in the season, causing necrosis (Keller et al. 2003). Similarly, $P$. syringae pv. syringae infection also induces necrosis in inflorescences but with the additional symptom of occasional visible bacterial ooze emerging from the plant tissues. Underreporting may also have been caused by the misdiagnosis of $P$. syringae pv. syringae as a physiological disorder. Prior to the Whitelaw-Weckert et al. (2011) study, symptoms of bacterial inflorescence rot in Tumbarumba were attributed to physiological causes: inflorescence necrosis and bunch-stem necrosis. Inflorescence necrosis and bunch-stem necrosis are induced by ammonium toxicity (Keller and Koblet 1995), and their symptoms include rachis or pedicel lesions and inflorescence or bunch abscission (Capps and Wolf 2000). The symptoms are similar to those of bacterial inflorescence rot, except that the bacterial disease causes the additional symptom of water-soaked appearance and bacterial ooze consisting of pure cultures of $P$. syringae $\mathrm{pv}$.

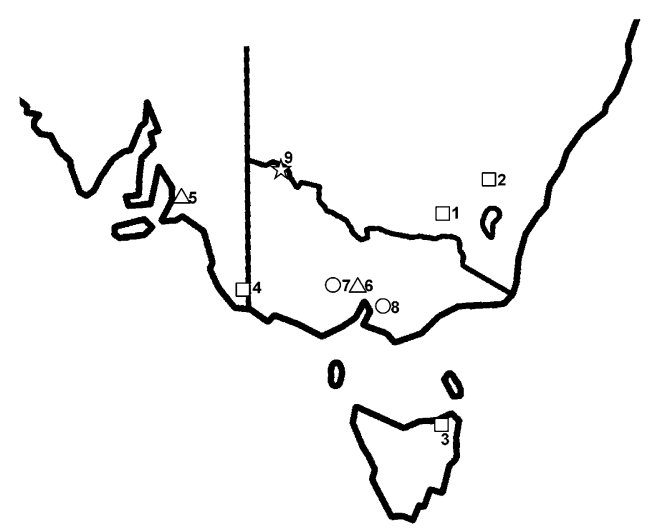

Fig. 5. Pseudomonas syringae pv. syringae isolated from eight cool-climate Australian grape vineyards plus one warm climate table-grape region with overhead watering system. $\square$ : $P$. syringae pv. syringae from diseased grapevines within cool-climate vineyards affected by bacterial inflorescence rot; (1) Tumbarumba, NSW; (2) Murrumbateman in the Southern Tablelands, NSW; (3) Piper's River, TAS; (4) Coonawarra, SA. $\Delta$ : P. syringae pv. syringae from cool-climate vineyards with grapevine bacterial leaf spot symptoms only; (5) Adelaide Hills, SA; and (6) Hanging Rock in the Macedon Ranges, VIC. O: $P$. syringae pv. syringae from apparently healthy grapevines in Victorian cool-climate vineyards not affected by bacterial inflorescence rot; (7) Glenlofty in the Pyrenees, VIC; (8) Hallston in Gippsland, VIC. $s$ : $P$. syringae pv. syringae from Red Globe and Sultana table grape in warm climate region Sunraysia, VIC (9) (reported by Victoria Department of Environment and Primary Industries Diagnostics Service, 16 November 1998, but not included in the current phylogenetic studies). syringae (Abkhoo 2015; Whitelaw-Weckert et al. 2011). The similarity of these symptoms may have led to $P$. syringae pv. syringae infections being underreported within the wine industry. Future investigations should include surveying inflorescences early in the season and comparing bunch numbers at harvest within vineyards containing known $P$. syringae pv. syringae infection.

Phenotypic identification. Phenotype-based methods for identifying $P$. syringae such as LOPAT can produce variable results depending on pathovar, host origin, or the nature of the bacterium itself (Lelliott and Stead 1987). The nonpathogenic grapevine $P$. syringae pv. syringae isolates (DAR82449, DAR82450, DAR82451, and DAR82452) were unable to cause tobacco leaf HR. Because the LOPAT protocol was devised for pathogenic bacteria, the protocol appears to have successfully differentiated between the pathogenic and nonpathogenic strains in our collection. This is consistent with the findings of Diallo et al. (2012), who demonstrated that their environmental $P$. syringae isolates were unable to cause HR in tobacco. The HR is the result of a cell death program used by plants to combat infecting bacteria. It is initiated by plant resistance proteins following recognition of effectors secreted into the plant cell by the invading bacteria to suppress host defenses. However, HR does not occur unless the bacteria have a functional type III secretion system (T3SS), which is encoded by the $h r p$ and $h r c$ genes (He 1996). The HR-negative isolates identified by Diallo et al. (2012) lacked at least one gene in the canonical hrp/hrc locus or the associated conserved effector locus which prevents them from initiating HR on tobacco. Further studies are required to investigate whether the nonpathogenic grapevine $P$. syringae pv. syringae isolates identified in the current study also contain mutations in the hrp/hrc locus.

Molecular characterization of isolates. The present study used $r p o B$ sequence typing and MLST analysis to confirm the identity of the DAR73915 isolate, originally collected by Hall et al. (2002) from the Adelaide Hills, as $P$. syringae pv. syringae. Interestingly, five $P$. syringae pv. syringae isolates collected from diseased grapevines in Tumbarumba, NSW were found to have $r p o B$ sequences identical to the DAR73915 Adelaide Hills isolate. Because the $r p o B$ gene has been established as a reliable marker for bacterial strain identification with high resolution for phylogenetic applications (Ait-tayeb et al. 2005; Mollet et al. 1997), these results indicate that the Adelaide Hills and Tumbarumba $P$. syringae pv. syringae isolates may have originated from the same source.

This study also used MLST data from four genes (gapA, gltA, gyrB, and $r p o D$ ) to characterize the core genome of $P$. syringae pv. syringae isolates collected from grapevines in Australian vineyards. The grape $P$. syringae pv. syringae isolates were grouped by MLST into two separate clades with excellent bootstrap support. Each clade contained a mixture of pathogenic (to grapevine) and nonpathogenic isolates. The clades also contained nongrape $P$. syringae pv. syringae hosts and a mixture of pathogenic (to grapevine) and nonpathogenic stains, indicating that $P$. syringae pv. syringae isolates in Australian vineyards are genetically diverse.

Pathogenicity. Not only did molecularly similar $P$. syringae pv. syringae isolates differ in pathogenicity toward grapevine but $P$. syringae pv. syringae isolates pathogenic to grapevine also had significantly different $r p o B$ and MLST sequences. In addition, some $P$. syringae pv. syringae isolates from nongrape hosts were positive for GPLTA pathogenicity testing on grapevine leaf discs, indicating a lack of host specificity and a potential source for cross-infection of grape from other horticultural crops, although further studies are required to investigate whether these nongrape isolates can cause grapevine BIR. These results are consistent with the results of Najafi and Taghavi (2014), who reported that $P$. syringae pv. syringae isolates obtained from diseased tissues of Prunus spp., beet, pear, quince, oat, millet, wheat, barley, and rice were all pathogenic to peach seedlings, regardless of the original host or position within a phylogenetic tree. Martín-Sanz et al. (2013) also showed that the core genome of $P$. syringae (by MLST) was only weakly associated with the pathovar designation and the plant host from which the bacteria were isolated. Pathogenicity and the preferred plant host are less 
likely to be directed by the core genome (e.g., as characterized by RAPD and MLST) than by the "flexible genome", which consists of genes encoding proteins responsible for adaptation to specific niches, evolving through horizontal exchange (Hwang et al. 2005). Further investigations are required to investigate horizontal transfer of genes encoding pathogenicity within the flexible genome of grapevine-pathogenic $P$. syringae pv. syringae.

Source of inoculum. The rpoB and MLST sequences of $P$. syringae pv. syringae isolate DAR82446, which was isolated from a necrotic rachis on a grapevine sucker shoot in a Tumbarumba vineyard, were identical to those of the pathogenic $P$. syringae pv. syringae isolates causing BIR within the same vineyard. Because DAR82446 was also positive for the GPLTA, this implies that grapevine sucker shoots may allow overwintering of pathogenic $P$. syringae pv. syringae. Similarly, $P$. avellanae, the causal agent of hazelnut bacterial canker, infects sucker shoots on hazelnut trees, and it has been suggested that latently infected sucker shoots used for propagation may have been the main vehicle for widespread dispersal of the pathogen in Italy (Scortichini 2002). In many fruit crops, $P$. syringae can also overwinter in buds, tissue around leaf scars, and at the margin of necroses and cankers (Bultreys and Kaluzna 2010). In addition, because $P$. syringae pv. syringae has been isolated from weeds (Geranium spp. and Malva spp.) within Californian stone fruit orchards affected by bacterial canker (Little et al. 1998), it is possible that $P$. syringae pv. syringae may overwinter on weeds within vineyards. The role of other plant species within the vineyard as potential sources of $P$. syringae pv. syringae inoculum and the progression of colonization within the grapevine host needs to be investigated.

Dispersion. The results of the current study demonstrate the general spread of $P$. syringae pv. syringae across cool-climate Australian vineyards. This is also supported by the phylogenetic data demonstrating similarity between isolates of $P$. syringae pv. syringae from grapevine tissue originating from separate vineyards (e.g., DAR82440 from Murrumbateman, NSW and DAR82442 from Piper's River, TAS). P. syringae may be dispersed by many mechanisms, including agricultural tools used in pruning and harvesting (Carroll et al. 2010). Hall et al. (2002) previously showed that BLS symptoms and disease severity increased in vineyards in subsequent seasons, and that transmission to other nearby vineyards may result. This suggests that the shared use of contaminated pruning equipment within and between vineyards may have resulted in disease spread (Lamichhane et al. 2014). This mode of transmission has also been observed with $P$. syringae from cherry (Carroll et al. 2010).

$P$. syringae may also be dispersed by soil particles (Hollaway and Bretag 1997), honey bees (Pattemore et al. 2014), insects and mammals (Bashan 1986), water sources (Morris et al. 2008), and precipitation from clouds (Clarke et al. 2010; Monteil et al. 2014; Morris et al. 2008, 2013). Interestingly, $P$. syringae pv. syringae infections of grapevines in cool-climate regions of Australia are often associated with heavy spring rains (Hall et al. 2002; Whitelaw-Weckert et al. 2011). Similarly, Hirano et al. (1996) demonstrated an association between bacterial populations and rainfall on bean cultivars. A comprehensive review conducted by Morris et al. (2013) indicated that the water cycle and rainfall are important for $P$. syringae pv. syringae movement through the environment. However, because $P$. syringae from water sources such as rainfall and snowmelt have been reported to lack essential T3SS effectors for virulence (Mohr et al. 2008), and humidity has been demonstrated to increase bacterial motility in bean (Leben et al. 1970), it is more likely that the increased disease in vineyards with heavy spring rain and overhead water sprinklers is caused by the increased humidity caused by these water sources. It will be important to determine whether the combination of high humidity and unclean pruning equipment plays a major role in motility and dispersal of this pathogen.

\section{Conclusions}

The results from this investigation provide the foundations for an improved understanding of the genetic structure and diversity of grapevine pathogen $P$. syringae pv. syringae. We have demonstrated that infection of Australian grapevines with pathogenic $P$. syringae pv. syringae occurs in at least six cool-climate viticultural regions plus one warmer region with overhead water spray irrigation. It is clear that genetically and pathogenically distinct strain groups of $P$. syringae pv. syringae can be isolated from grapevines, and that genetically distinct strain groups of $P$. syringae pv. syringae from other plant hosts may infect grapevine.

On the basis of this study, we conclude that the presence of $P$. syringae pv. syringae in Australian cool-climate vineyards may pose a threat to the Australian wine industry. Damage caused by $P$. syringae pv. syringae can lead to severe economic losses. Furthermore, some isolates of $P$. syringae pv. syringae lack host specificity and, therefore, may be transmitted from one crop to another. The isolation of pathogenic $P$. syringae pv. syringae from grapevine sucker shoots also suggests that sucker shoots allow overwintering of the pathogen. The vineyard quarantine status of $P$. syringae pv. syringae may need to be reconsidered, due to its easy dispersal through pruning and other equipment. Appropriate quarantine measures and sterilization of pruning machinery are highly recommended in susceptible vineyards.

\section{Acknowledgments}

We thank T. Hill (Colorado State University) and R. Shivas and Y. P. Tan (Department of Agriculture, Fisheries, and Forestry in Queensland) for their generous gifts of $P$. syringae isolates; and Mr. Nathan Scarlett (deceased), who collected the Coonawarra vineyard necrotic rachis samples.

\section{Literature Cited}

Abkhoo, J. 2015. Bacterial inflorescence rot of grapevine caused by Pseudomonas syringae pv. syringae in Iran. Aust. J. Appl. Math. 5:29-32.

Ait-tayeb, L. A., Ageron, E., Grimont, F., and Grimont, P. A. D. 2005. Molecular phylogeny of the genus Pseudomonas based on $r p o B$ sequences and application for the identification of isolates. Res. Microbiol. 156:763-773.

Alfrose, S., Hossain, I., Islam, M. R., Hossain, M. D., and Khan, M. A. H. 2014 RAPD analyses reveals the genetic diversity of the litchi leaf blight pathogen, Pseudomonas syringae pv. syringae in Bangladesh. Curr. Res. Microbiol. Biotechnol. 2:301-309.

Bashan, Y. 1986. Field dispersal of Pseudomonas syringae pv. tomato, Xanthomonas campestris pv. vesicatoria, and Alternaria macrospora by animals, people, birds, insects, mites, agricultural tools, aircraft, soil particles, and water sources. Can. J. Bot. 64:276-281.

Bultreys, A., and Kaluzna, M. 2010. Bacterial cankers caused by Pseudomonas syringae on stone fruit species with special emphasis on the pathovars syringae and morsprunorum race 1 and race 2. J. Plant Pathol. 92:S21-S33.

Bureau of Meteorology. 2012. Annual and monthly potential frost days. Online publication. http://www.bom.gov.au/jsp/ncc/climate_averages/frost/index.jsp

Capps, E. R., and Wolf, T. K. 2000. Reduction of bunch stem necrosis of Cabernet Sauvignon by increased tissue nitrogen concentration. Am. J. Enol. Vitic. 51: 319-328.

Carroll, J., Robinson, T., Burr, T., Hoying, S., and Cox, K. 2010. Evaluation of pruning techniques and bactericides to manage bacterial canker of sweet cherry. N. Y. Fruit Q. 18:9-15.

Cazorla, F. M., Tores, J. A., Olalla, L., Perez-Garcia, A., Farre, J. M., and de Vicente, A. 1998. Bacterial apical necrosis of mango in Southern Spain: A disease caused by Pseudomonas syringae pv. syringae. Phytopathology 88 614-620.

Clarke, C. R., Cai, R., Studholme, D. J., Guttman, D. S., and Vinatzer, B. A. 2010 Pseudomonas syringae strains naturally lacking the classical $P$. syringae hrp/hrc locus are common leaf colonizers equipped with an atypical type III secretion system. Mol. Plant-Microbe Interact. 23:198-210.

Cohen, Y., Reuveni, M., and Baider, A. 1999. Local and systemic activity of BABA (DL-3-aminobutyric acid) against Plasmopara viticola in grapevines. Eur. J. Plant Pathol. 105:351-361.

Cugusi, M., Garau, R., Prota, U., and Dore, M. 1986. A bark necrosis of grapevine caused by Pseudomonas syringae V. Hall, in Sardinia. J. Phytopathol. 116: 176-185.

Diallo, M. D., Monteil, C. L., Vinatzer, B. A., Clarke, C. R., Glaux, C., Guilbaud, C., Desbiez, C., and Morris, C. E. 2012. Pseudomonas syringae naturally lacking the canonical type III secretion system are ubiquitous in nonagricultural habitats, are phylogenetically diverse and can be pathogenic. ISME J. 6: 1325-1335.

Feil, H., Feil, W. S., Chain, P., Larimer, F., DiBartolo, G., Copeland, A., Lykidis, A., Trong, S., Nolan, M., Goltsman, E., Thiel, J., Malfatti, S., Loper, J. E., Lapidus, A., Detter, J. C., Land, M., Richardson, P. M., Kyrpides, N. C., Ivanova, N., and Lindow, S. E. 2005. Comparison of the complete genome sequences of Pseudomonas syringae pv. syringae B728a and pv. tomato DC3000. Proc. Natl. Acad. Sci. USA 102:11064-11069.

Felsenstein, J. 1985. Confidence limits on phylogenies: An approach using the bootstrap. Evolution 39:783-791. 
Gardan, L., Shafik, H., Belouin, S., Broch, R., Grimont, F., and Grimont, P. A. D. 1999. DNA relatedness among the pathovars of Pseudomonas syringae and description of Pseudomonas tremae sp. nov. and Pseudomonas cannabina sp. nov. (ex Sutic and Dowson 1959). Int. J. Syst. Bacteriol. 49:469-478.

Golzar, H., and Cother, E. J. 2008. First report of bacterial necrosis of mango caused by Pseudomonas syringae pv. syringae in Australia. Australas. Plant Dis. Notes 3:107-109.

Hacker, J., and Carniel, E. 2001. Ecological fitness, genomic islands and bacterial pathogenicity. EMBO Rep. 2:376-381.

Hall, B., McMahon, R., Noble, D., Cother, E., and McLintock, D. 2002. First report of Pseudomonas syringae on grapevines (Vitis vinifera) in South Australia. Australas. Plant Pathol. 31:421-422.

He, S. Y. 1996. Elicitation of plant hypersensitive response by bacteria. Plant Physiol. 112:865-869.

Hirano, S. S., Baker, L. S., and Upper, C. D. 1996. Raindrop momentum triggers growth of leaf-associated populations of Pseudomonas syringae on field-grown snap bean plants. Appl. Environ. Microbiol. 62:2560-2566.

Hollaway, G. J., and Bretag, T. W. 1997. Survival of Pseudomonas syringae pv. pisi in soil and on pea trash and their importance as a source of inoculum for a following field pea crop. Aust. J. Exp. Agric. 37:369-375.

Hwang, M. S. H., Morgan, R. L., Sarkar, S. F., Wang, P. W., and Guttman, D. S. 2005. Phylogenetic characterization of virulence and resistance phenotypes of Pseudomonas syringae. Appl. Environ. Microbiol. 71:5182-5191.

Jukes, T. H., and Cantor, C. R. 1969. Evolution of protein molecules. Pages 21-132 in: Mammalian Protein Metabolism. H. N. Munro, ed. Academic Press, New York.

Keller, M., and Koblet, W. 1995. Stress-induced development of inflorescence necrosis and bunch-stem necrosis in Vitis vinifera $\mathrm{L}$. in response to environmental and nutritional effects. Vitis 34:145-150.

Keller, M., Viret, O., and Cole, F. M. 2003. Botrytis cinerea infection in grape flowers: Defense reaction, latency, and disease expression. Phytopathology 93:316-322.

Klingner, A. E., Palleroni, N. J., and Pontis, R. E. 1976. Isolation of Pseudomonas syringae from lesions on Vitis vinifera. J. Phytopathol. 86:107-116.

Kumar, S., Tamura, K., and Nei, M. 2004. MEGA3: Integrated software for molecular evolutionary genetics analysis and sequence alignment. Brief. Bioinf. 5:150-163.

Lamichhane, J. R., Varvaro, L., Parisi, L., Audergon, J. M., and Morris, C. E. 2014. Disease and frost damage of woody plants caused by Pseudomonas syringae: Seeing the forest for the trees. Adv. Agron. 126:235-295.

Leben, C., Schroth, M., and Hildebrand, D. 1970. Colonization and movement of Pseudomonas syringae on healthy bean seedlings. Phytopathology 60:677-680.

Lelliott, R. A., Billing, E., and Hayward, A. C. 1966. A determinative scheme for the fluorescent plant pathogenic Pseudomonads. J. Appl. Microbiol. 29: 470-489.

Lelliott, R. A., and Stead, D. E. 1987. Methods for the Diagnosis of Bacterial Diseases of Plants, Vol. 2. Blackwell Publishing Ltd./British Society for Plant Pathology, Oxford

Lindeberg, M., Cunnac, S., and Collmer, A. 2009. The evolution of Pseudomonas syringae host specificity and type III effector repertoires. Mol. Plant Pathol. 10: 767-775.

Little, E. L., Bostock, R. M., and Kirkpatrick, B. C. 1998. Genetic characterization of Pseudomonas syringae pv. syringae strains from stone fruits in California. Appl. Environ. Microbiol. 64:3818-3823.

Mansvelt, E. L., and Hattingh, M. J. 1987. Scanning electron microscopy of colonization of pear leaves by Pseudomonas syringae pv. syringae. Can. J. Bot. 65:2517-2522.

Mansvelt, E. L., and Hattingh, M. J. 1989. Scanning electron microscopy of invasion of apple leaves and blossoms by Pseudomonas syringae pv. syringae. Appl. Environ. Microbiol. 55:533-538.
Martín-Sanz, A., de la Vega, M. P., Murillo, J., and Caminero, C. 2013. Strains of Pseudomonas syringae pv. syringae from pea are phylogenetically and pathogenically diverse. Phytopathology 103:673-681.

Melotto, M., Underwood, W., Koczan, J., Nomura, K., and He, S. Y. 2006. Plant stomata function in innate immunity against bacterial invasion. Cell 126 969-980.

Mohr, T. J., Liu, H., Yan, S., Morris, C. E., Castillo, J. A., Jelenska, J., and Vinatzer, B. A. 2008. Naturally occurring nonpathogenic isolates of the plant pathogen Pseudomonas syringae lack a type III secretion system and effector gene orthologues. J. Bacteriol. 190:2858-2870.

Mollet, C., Drancourt, M., and Raoult, D. 1997. rpoB sequence analysis as a novel basis for bacterial identification. Mol. Microbiol. 26:1005-1011.

Monteil, C. L., Bardin, M., and Morris, C. E. 2014. Features of air masses associated with the deposition of Pseudomonas syringae and Botrytis cinerea by rain and snowfall. ISME J. 8:2290-2304.

Moragrega, C., Llorente, I., Manceau, C., and Montesinos, E. 2003. Susceptibility of European pear cultivars to Pseudomonas syringae pv. syringae using immature fruit and detached leaf assays. Eur. J. Plant Pathol. 109:319-326.

Morris, C. E., Monteil, C. L., and Berge, O. 2013. The life history of Pseudomonas syringae: Linking agriculture to earth system processes. Annu. Rev. Phytopathol. 51:85-104

Morris, C. E., Sands, D. C., Vinatzer, B. A., Glaux, C., Guilbaud, C., Buffière, A. Yan, S., Dominguez, H., and Thompson, B. M. 2008. The life history of the plant pathogen Pseudomonas syringae is linked to the water cycle. ISME J. 2:321-334.

Najafi, P. H. G., and Taghavi, S. M. 2014. Discrimination of Pseudomonas syringae pv. syringae isolates from different hosts in Iran using pathogenicity tests and RAPD. Int. J. Agric. Sci. 4:16-27.

Pattemore, D. E., Goodwin, R. M., McBrydie, H. M., Hoyte, S. M., and Vanneste, J. L. 2014. Evidence of the role of honey bees (Apis mellifera) as vectors of the bacterial plant pathogen Pseudomonas syringae. Australas. Plant Pathol. 43:1-5.

Richardson, H. J., and Hollaway, G. J. 2011. Bacterial blight caused by Pseudomonas syringae pv. syringae shown to be an important disease of field pea in south eastern Australia. Australas. Plant. Pathol. 40:260-268.

Saitou, N., and Nei, M. 1987. The neighbour-joining method: A new method for reconstructing phylogenetic trees. Mol. Biol. Evol. 4:406-425.

Samedov, A. N., Mogilevskaya, M. I., Karagezov, T. G., Khudaverdieva, S. R. and Aliev, L. A. 1988. Detection of the causal agents of grape bacteriosis in Aspheron (Azebaijan SSR, USSR). Izv. An. Azerb. SSR. 6:18-23.

Sarkar, S. F., Gordon, J. S., Martin, G. B., and Guttman, D. S. 2006. Comparative genomics of host-specific virulence in Pseudomonas syringae. Genetics 174: 1041-1056.

Sarkar, S. F., and Guttman, D. S. 2004. Evolution of the core genome of Pseudomonas syringae, a highly clonal, endemic plant pathogen. Appl. Environ. Microbiol. 70:1999-2012.

Sawada, H., Suzuki, F., Matsuda, I., and Saitou, N. 1999. Phylogenetic analysis of Pseudomonas syringae pathovars suggests the horizontal gene transfer of $\operatorname{argK}$ and the evolutionary stability of $h r p$ gene cluster. J. Mol. Evol. 49:627-644.

Scortichini, M. 2002. Bacterial canker and decline of European hazelnut. Plant Dis 86:704-709.

Whitelaw-Weckert, M. A., Whitelaw, E. S., Rogiers, S. Y., Quirk, L., Clark, A. C. and Huang, C. X. 2011. Bacterial inflorescence rot of grapevine caused by Pseudomonas syringae pv. syringae. Plant Pathol. 60:325-337.

Yamamoto, S., Kasai, H., Arnold, D. L., Jackson, R. W., Vivian, A., and Harayama, S. 2000. Phylogeny of the genus Pseudomonas: Intrageneric structure reconstructed from the nucleotide sequences of $g y r B$ and $r p o D$ genes. Microbiology 146:2385-2394.

Young, A. 2008. Notes on Pseudomonas syringae pv. syringae bacterial necrosis of mango (Mangifera indica) in Australia. Australas. Plant Dis. Notes 3:138-140. 